TI 2011-147/3

Tinbergen Institute Discussion Paper

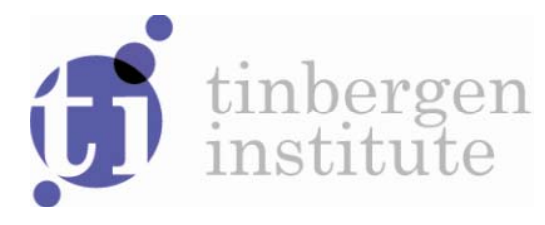

Migrants and International Economic Linkages:

A Meta-Overview

Masood Gheasi

Peter Nijkamp*

Piet Rietveld*

Faculty of Economics and Business Administration, VU University Amsterdam.

* Tinbergen Institute. 
Tinbergen Institute is the graduate school and research institute in economics of Erasmus University Rotterdam, the University of Amsterdam and VU University Amsterdam.

More TI discussion papers can be downloaded at http://www.tinbergen.nl

Tinbergen Institute has two locations:

Tinbergen Institute Amsterdam

Gustav Mahlerplein 117

1082 MS Amsterdam

The Netherlands

Tel.: +31(0)205251600

Tinbergen Institute Rotterdam

Burg. Oudlaan 50

3062 PA Rotterdam

The Netherlands

Tel.: +31(0)10 4088900

Fax: $+31(0) 104089031$

Duisenberg school of finance is a collaboration of the Dutch financial sector and universities, with the ambition to support innovative research and offer top quality academic education in core areas of finance.

DSF research papers can be downloaded at: http://www.dsf.nl/

Duisenberg school of finance

Gustav Mahlerplein 117

1082 MS Amsterdam

The Netherlands

Tel.: +31(0)20 5258579 


\title{
MIGRANTS AND INTERNATIONAL ECONOMIC LINKAGES: A META-OVERVIEW
}

\author{
Masood Gheasi ${ }^{1}$, Peter Nijkamp ${ }^{2}$ and Piet Rietveld ${ }^{3}$ \\ Department of Spatial Economics \\ VU University \\ Amsterdam, the Netherlands \\ ${ }^{1}$ mgheasi@feweb.vu.nl \\ 2pnijkamp@feweb.vu.nl \\ 3prietveld@feweb.vu.nl
}

\begin{abstract}
The rapid growth in the foreign-born population in many high and middle-income countries in the past decades has prompted much research on the socio-economic impacts of immigration. The migration issue has become one of the most debated subjects in many developed countries. Since the early 1990s, many applied studies have been conducted on the impact of international migration on international trade, foreign direct investment, and tourism. These studies have largely adopted the same specification, viz. the log-linear gravity model in combination with the knowledge capital model, where the (logarithm of the) stock of migrants from a specific source country may be included as an additional explanatory variable. Our study provides a concise review of the relationship between migrants and their international economic linkages. It then focuses on Foreign Direct Investment (FDI), for both inward and outward FDI. The main aim of our study is to offer a synthesis by means of a metaanalysis of various studies undertaken worldwide, in order to test the robustness of the relationship between migration and foreign direct investment. Our primary results confirm that immigration has a positive impact on FDI investment in both directions (inward and outward), and that these impacts are higher when migrants are highly-educated and skilled.
\end{abstract}

Keywords: immigration, diasporas, foreign direct investment, gravity model, meta-analysis 


\section{The Age of Mobility and Migration}

Geographical mobility - either short-range (e.g. commuting, social visits) or long-range (e.g. international tourism, migration) - is on a rising edge. According to Chatwin (1988), at the beginning of our era the average distance a person travelled over an entire lifetime was approximately 15,000 km. The prevailing transportation technology and infrastructure in the ancient past did not allow people to be highly mobile, apart from a few adventurers. At that time, the total distance travelled in the course of a life was equal to the distance of one transatlantic flight between Europe and the USA. With the emergence of the Industrial Revolution (19th century), transportation technology improved significantly, as a result of the introduction of the steam engine, and, consequently, the average mobility of people quadrupled in the space of a few generations. This led to a structural rise in mobility over the past century, with an average annual distance travelled per person at the beginning of this century equal to about $5000 \mathrm{~km}$. The latter figure has a very skewed distribution, however, with very high mobility rates of people from the developed world, and with a disproportionate share of aviation as a transport mode.

The drastic improvements in transportation and communication technology have not only induced a rapid rise in short-term geographical mobility (such as commuting and vacation trips) but have also laid the foundations for a structural rise in international migration. Over the past few decades crossborder migration has become a mega-trend of a globalizing economy, to the extent that some people ever speak of the 'age of migration' (see also Goldin et al. 2011; Nijkamp 2010).

A few figures may serve to illustrate the dimensions of the international migration phenomenon. At present, more that 200 million people - some 3 per cent of the world population - are living outside their country of origin, with significant variations in immigration rates and net-migration rates per country (for statistical details, see among others GCIM 2005; IOM 2010; OECD 2009; UNDP 2009; United Nations 2004; World Bank 2006). By the beginning of this century some 13 to 17 million Islamic people had found a permanent residence in Western Europe (see Caldwell 2009), a number which corresponds to approx. 5 per cent of the Western-European population. And, in a small open country like the Netherlands, some 20 per cent of the population have a migrant (first- and second generation) background; the share of non-Western migrants in the Dutch population is about 11 per cent.

Migrants form a very heterogeneous population group, with a variety of migration motives, e.g. labour migration, knowledge migration, climate migration, social migration, etc. In a recent OECD study (2009) much attention is paid to the increasing importance of, and intensifying competition among, skilled migrants (see also Berkhout et al. 2007; Poot et al. 2008).

In most countries, rising flows of international migrants have in the past and the present prompted fierce debates on the desirability or acceptability of international migration (for a review, see Hatton and Williamson 2006). The negative perceptions of foreign in-migration originate mainly from three types of arguments: crowding-out effects on the labour market; disproportionate use of social welfare benefits; and anti-social or criminal behaviour. It should be added that most of the (perceived 
and real) disadvantages are found in large urban concentrations (see Snel and Burgers 2000; Dagevos 2006).

The migration debate calls for evidence-based research on the socio-economic consequences of the influx of migrants for the host country concerned. This prompts the need for a solid 'migration impact assessment' (see Nijkamp et al. 2011). The next section is devoted to a brief overview of the state of the art in migration impact analysis. Next we zoom in on a particular class of migrant effects, viz. the contribution of migrants to international economic relations (in particular, trade, tourism and Foreign Direct Investment (FDI)). Then we focus our attention on one specific empirical issue in this context, viz. the contribution of migration to FDI. Subsequently, we will carry out a meta-analysis of previously undertaken quantitative studies on the FDI effects of migration.

\section{Migration Impact Assessment (MIA)}

Migrants have a variety of impacts on local, regional, and national economies in the host country: for instance, on the demographic composition, on social cohesion, on the labour market, on business life, etc. Several of these impacts have direct and indirect economic and financial dimensions, such as tax payments, unemployment benefits, consumer expenditures, remittances, etc. In addition, there may be intangible effects, such as the rise in cultural diversity, the contribution to innovativeness and creativeness, or the rise in international cooperation. These issues have led to the emergence of migration impact assessment (MIA) as an evidence-based scientific investigation into the direct and indirect socio-economic effects of foreign immigration on the local, regional or national economies of a host country. A great variety of MIAs can be found in the literature (see, e.g., Borjas 2005; Poot 2008; Samuel and George 2002; Sarvimäki 2009; Saxenian 2007). In Nijkamp (2010) an illustrative overview of different MIAs from various countries (e.g. New Zealand, Australia, UK, Germany, the Scandinavian countries, the US States, and the EU Member States) is given. There appears to be a vast array of specific research concerns and methodological approaches in these studies. But the overwhelmingly evident conclusion from this diversity of research approaches is that the often-heard complaints about negative impacts of migrants are not supported by empirical facts: migrants tend to have a neutral or modest positive effect on local labour markets, regional development, and spatial distributions (see Bakens and Nijkamp 2010; Nijkamp and Poot 2011).

Migration impacts can be divided into various distinct categories (see also Boeri and Brücker 2005; Pekkala 2005; Nijkamp 2010), as shown in subsections 2.1-2.5.

\subsection{Labour market effects}

These effects refer to wage developments and/or (un)employment conditions of natives as a consequence of migrant entries to the labour market. The scientific challenge in this field is not to look at direct correlations between these two phenomena, but to position labour market impacts of migrants 
in a broader context. For example, the earnings gap literature stipulates that the duration of stay of a migrant determines his income (and the income differences between migrants and natives), so that newcomers are always in a less-privileged position. Convergence of wages and employment conditions will only be achieved if the average wages of migrants grow faster than those of the natives, but then migrants obviously lose their competitive advantage (which reduces convergence trends). Thus, the analysis of labour market disparities is fraught with many short- and long-term, direct and indirect competition effects.

The labor market effects of migrants have been investigated in many empirical studies. And recently, several meta-analytical modelling efforts have been undertaken by Longhi et al. (2005a, 2005b, 2008a, 2008b, 2009) on the wage and job effects of migrants. The final conclusions from these comparative studies are rather straightforward: there is no evidence that migration has significantly negative impacts on the wages or employment of natives. In other words, the crowding-out hypothesis does not find a clear justification in the international empirical literature.

\subsection{Welfare effects}

Welfare effects refer to income, and income convergence, and distribution effects. Again, these effects have been extensively studied in the international literature. A recent meta-analytic study by Ozgen et al. (2010a) shows that the overall effect of immigration on income convergence is slightly negative, although the authors also find that a positive net migration favours economic growth, so that the net effect is somewhat ambiguous, but by no means a priori negative. Clearly, higher positive welfare effects are found, if the skill level of migrants is higher. Also in this context, the duration of stay and the geographical scale of analysis are intervening factors.

\subsection{Business effects}

Migrants have to make a living often under problematic circumstances. It is, therefore, no wonder that many migrants resort to ethnic or migrant entrepreneurship as a source of income ('the stranger is the trader') (see Waldinger 1990; Baycan-Levent and Nijkamp 2009). This phenomenon has become a popular research topic in the business economics literature. Several empirical studies have been carried out by Sahin et al. $(2007,2010)$ and Nijkamp et al. (2010). The overall conclusions from various studies are that migrant entrepreneurs make up an increasing share of SMEs in western urban agglomerations, that they are able to fill important niche-markets (e.g. ethnic products), and that they are increasingly oriented towards upscaling their activities (Kourtit and Nijkamp 2011). The overall finding of an abundance of migrant entrepreneurship studies is that migrant business leads to an upgrade of the economic vitality of western cities. 


\subsection{Cultural diversity and innovation effects}

Since the seminal work of Jane Jacobs (1961) on the 'urban melting pot' hypothesis, much research work has been undertaken on the impacts of cultural diversity - mainly as a consequence of foreign migrants - on the socio-economic development of an area. This effect has recently been investigated in a quantitative modelling study of Ozgen et al. (2010b), who come to the conclusion that for NUTS 2 regions in Europe, the degree of innovation runs parallel to the share of migrants. Migrants are often concentrated in urban agglomerations, and the authors also find that a positive population growth in urban areas leads to more innovations. And, finally, the authors find that skill levels and the country of origin of migrants have a positive welfare effect. Their conclusion is that cultural-ethnic diversity favours the regional innovation potential (see also Baycan-Levent 2010).

\subsection{International linkages}

Migration reflects international trade in labour. It is, therefore, plausible that international linkages - trade, tourism, FDI - are favoured by migration. This issue is addressed in a more detailed way in the remaining part of this paper. We begin with a summary of the existing literature (Section 3 ), and later in Section 4 we provide a quantitative synthesis of the empirical literature through the use of metaanalytical modelling.

\section{Migration and International Economic Impacts}

Labour migration among countries is essentially a specific form of international trade. It is well known from the trade literature that the benefits of trade are higher, the more the countries involved have a more diversified socio-economic structure. An exchange of uniform workers would by definition not have a welfare-enhancing effect. Thus, diversification and complementarity are key for successful international migration.

In the recent macroeconomic literature we observe an increasing interest in the triangle of international migration, trade in goods and services, and Foreign Direct Investment (FDI) (see e.g. Mattoo and Carzaniga 2003; ODI 2008; Poot and Strutt 2009). It is noteworthy that, despite clear similarities in international flows of goods and of people, the policy treatment of these flows differs vastly. In contrast to trade, international migration is subject to a multitude of institutional rules and regulatory systems (see Chia 2006; Plane and Hoffman 2009). Consequently, there may be some parallel movements between international flows of people and goods, but there is no a priori linear correlation. This can be illustrated from the trade and migration statistics in OECD countries: the ratio of immigrants to the native population is approx. 6 per cent, whereas the ratio of imports to GNP is approx. 27 per cent (see Hatton 2007).

Furthermore, the foreign investments of a given country are essentially a complement to immigration: instead of importing people, production is outsourced (see Gera et al. 2004; Kugler and 
Rapoport 2007). The relative importance of both phenomena depends, of course, on the relative factor prices and the market potential in the destination country.

And, finally, international trade is influenced by, the transaction costs between the countries of origin and destination. Several migration-related factors have an impact on the economic relationship between two countries (see, e.g., Bryant et al. 2004; Poot and Strutt 2009). Firstly, there are generic income and trade effects from the rise in welfare as a consequence of economic efficiency increases from international labour migration. Next, the limited access of immigrants to local labour markets caused by language, cultural, and social barriers - forces them to resort to self-employment migrant business activities ('the stranger is the trader'), which may occupy specific ethnic market niches (see Dunlevy and Hutchinson 1999; Kourtit and Nijkamp 2011). In the third place, most migrants still keep social bonds with their country of origin, so that through this medium international connectivity - and hence also trade - is encouraged (see World Bank 2006), while their taste preferences for products from their original country may have a positive influence on the international trade of specific goods. And, finally, most migrants are rather familiar with the operation of markets in their countries of origin, so that transaction costs (including trade risks) may be lower (see Gould 1994; Girma and Yu 2002; Wolf 2000; and Combes et al. 2003).

As a result of the above factors, it seems plausible to assume that the import effects of migration may be larger than the export effects. The order of magnitude of these effects is co-determined by the skill levels of migrants and their duration of stay (see also Ching and Chen 2000; Dunlevy and Hutchinson 1996; Münz et al. 2006; Rauch and Trindade 2002; White 2007).

Several case studies confirm the above observations (see also OECD 2003). For example, BlanesCristóbal (2003) concludes that immigration in Spain has reinforced the trade intensity with various countries of migration origin. Law et al. (2009) find for New Zealand that a 10 per cent rise of migrants from a source country means a rise of 0.6 per cent in exports to that country and a rise of 1.9 per cent in imports from that country. And Mundra (2005) comes to the conclusion that the immigration effect on imports in the US is positive for both final and intermediate goods, while this effect on exports is only positive for final goods. Finally, Lewer and van den Berg (2009) argue that, on average, in all OECD countries a 10 per cent rise in immigration from an origin country to a destination country leads to an increase in total trade between those two countries of 4.5 per cent age points.

Clearly, international tourism is a very special sector in the foreign trade sector. It seems plausible that trade connections favour international visits, while tourist visits may also induce international trade (see WTTC 2006; Matias et al. 2007, 2009; van Leeuwen 2009; Gheasi et al. 2011). A particular role is played by VFR tourism ('visits to friends and relatives') (see Williams and Hall 2000). Various case studies can be found in Seaton and Palmer (1997) and Cohen and Harris (1998). On the relationship between tourism and migration interactions, we refer to studies by Dwyer et al. (1993) - who argue that a rise in migration of 10 per cent in Australia leads to an increase in VFR-tourists of 5.5 per cent -, by Seetaram 
(2008) - who argues that the effect of immigration on the demand for tourist services in Australia is relatively higher than the effects of trade growth or population growth ; and by CAA (2009) - which observes a significant relationship between migration and GNP in the UK and a weaker relationship between VFR-tourism and GNP.

The previous empirical evidence is clearly somewhat anecdotal, but it is clear that a positive correlation between migration and trade (and tourism) may be hypothesized. This would call for a more solid empirical test framework, based on a synthesis of many studies on the migration-trade nexus (see also a study by Genc et al. 2010). A more specific application will be undertaken next in Section 4 on the migration-FDI nexus.

\section{Migration and FDI: A Meta-Overview}

Meta-analysis is the technique of statistically combining the results of different studies that largely address the same impact question. One objective of meta-analysis is to test the null hypothesis that a pooled combination of different point estimates is equal to zero when findings from the entire area of research are combined (Cipollina and Salvatici, 2010). Meta-analysis became a popular and valuable tool, thanks to the work of Glass and Smith (1979), among others. Nowadays, this method is applied in many different research fields in economics. For example Longhi et al. (2005a) studied the impact of immigration on wages; Brander et al. (2007) studied eco-tourism; Cipollina and Salvatici (2010) studied the impact of trade agreements on trade flows; Card et al. (2010) carried out an analysis of evaluations of active labour market policy; Genc et al. (2010) studied the impact of migration on international trade; and in 2005 the Journal of Economic Surveys devoted a whole special issue (Vol. 19, No.3) to this approach.

The extraction of uniform results from different studies may be problematic when decision makers are trying to use background research as a basis for decisions without having available actual case-study records specific to their own situation (Holmgren, 2007). This problem is more common in economics, because the set of independent explanatory variables is often different across studies, while the decision maker may wish to assess the joint effect of the full range of variables. The problem can also be observed at different geographical scale levels. Meta-analysis is a tool that can be used to address such problems.

\subsection{Data}

In this application, we analyse whether highly-educated, poorly-educated, skilled and low-skilled migrants have an impact on FDI outward and inward from and to the host country by comparing studies 
that report one or more estimates of this impact. A notable feature of the studies in this field is that the host countries for the migrants considered are almost without exception OECD countries. So these studies consider the effect of inward migration from the perspective of well-developed countries on inward and outward FDI with respect to other countries in the world. A small number of these studies also consider the effect on inward and outgoing FDI of outward migration, i.e. of residents of the welldeveloped country who have migrated to other countries. To distinguish the two approaches we use the term 'diaspora' for the latter category. In order to acquire a systematic and representative set of studies, we selected all articles that contain FDI (inward and/or outward) as the dependent variable, and immigration as an explanatory variable. The dependent variable in our meta-analysis is the elasticity of outward or inward FDI with respect to migration. We used only publications written in English language. We do not expect this to be a source of bias in the present application. Papers were also selected via an extensive search on Google Scholar; in this way, we also accessed working papers that are not published in academic journals. We also used the technique of snowballing, viz. carefully scanning through the references of studies included. It is noteworthy that there is a high degree of comparability of results between the published and the unpublished papers in our database.

Our final sample includes nine publications (three published in academic journals, and six working papers or unpublished studies). These yielded up to 167 regressions from which the migrant (emigrant, immigrant or both) elasticity of outward and/or inward FDI could be derived. We have in total 140 point estimates for outward FDI, and 125 point estimates for inward FDI. Table 1 lists the studies, and the countries to which the analysis pertains.

We then divided the studies into two classes, viz. published articles and unpublished articles. It seems plausible that published studies tend to include more accurate econometric analyses, because they pass a series of tests and amendments before publication. Many study characteristics are coded as dummy variables, equal to 1 for each regression that has a particular attribute. Other study characteristics are numerical, such as the dates of the observations of the primary study. We also recorded the econometric methodology employed to estimate the gravity model. A distinction was made between OLS, the Tobit model, IV, 3SLS, and GMM. With respect to the specification, it was also noted whether a fixed-effects or random-effects panel data-generating process was assumed, and whether the model was static or allowed for autocorrelation. 
Table 1: Statistics used in the meta-analysis

\begin{tabular}{|c|c|c|c|c|}
\hline Study & $\begin{array}{l}\text { \# of estimated } \\
\text { equations }^{\mathrm{a}}\end{array}$ & $\begin{array}{l}\text { Time } \\
\text { period }\end{array}$ & Country & $\begin{array}{l}\text { Outward/ } \\
\text { Inward }\end{array}$ \\
\hline Gao (2003) & 2 & 1984-1997 & China & Inward \\
\hline Dolman (2007) & 12 & $2000-2000$ & OECD & Outward \& inward \\
\hline \multirow{4}{*}{ Murat and Flisi (2007) } & \multirow{4}{*}{27} & $1991-2004$ & Germany & Outward \& inward \\
\hline & & $1990-2004$ & Italy & Outward \& inward \\
\hline & & 1990-1999 & France & Outward \& inward \\
\hline & & 1990-1995 & United Kingdom & Outward \& inward \\
\hline Murat and Pistoresi (2009) & 7 & $1990-2005$ & Italy & Outward \& inward \\
\hline \multirow{5}{*}{ Murat and Flisi (2009) } & \multirow{5}{*}{75} & 1990-1999 & France & Outward \& inward \\
\hline & & $1991-2006$ & Germany & Outward \& inward \\
\hline & & $2002-2005$ & Italy & Outward \& inward \\
\hline & & $2003-2006$ & Spain & Outward \& inward \\
\hline & & $1990-2001$ & United Kingdom & Outward \& inward \\
\hline Javocik et al. (2010) & 30 & $1990-2000$ & US & Outward \\
\hline Lewer and van den Berg (2010) & 1 & $1991-2000$ & OECD & Outward \& inward \\
\hline Simone and Manchin (2010) & 7 & $1995-2007$ & EU15 & Inward \\
\hline Gheasi et al. (2011) & 6 & $2001-2007$ & UK & Outward \& inward \\
\hline
\end{tabular}

Note: In most cases the elasticity of FDI with respect to the stock of migrants is estimated for various levels of education.

The dimensions of the panel data (first year, final year, number of cross-sections, observations per cross-section, number of host countries or regions, number of home countries) are also taken into account. While the core specification was very similar across most studies, some covariates did vary between studies. Dummy variables therefore indicated the presence of the following covariates: migrants with tertiary education; migrants with primary education; skilled migrants; low-skilled migrants; diasporas; diasporas in OECD countries; diasporas in non-OECD countries; population; distance; colonial ties; conflict; institution quality.

The institution quality in the studies covered for our meta-analysis represents the quality of the business climate, and it is measured by using the average of voice and accountability, political stability, government effectiveness, regulatory quality, rule of law, and control of corruption from the 'governance matters' indicator developed by Kaufmann et al. (2009) or from the WorldBank Institute, Governance \& Anti-Corruption - Aggregate Governance Indicators. 


\subsection{Descriptive analysis}

Our descriptive statistics show a great degree of heterogeneity across studies. Table 2 below presents the descriptive statistics by country. The mean values of the outward and inward FDI elasticities are positive. The ranges are broad, and when we look at the negative elasticities, the UK has the highest negative elasticity in outward FDI (-0.779), and it also has the most positive elasticity (1.703). For inward FDI even larger variations are observed. Table 2 thus shows that that there is a strong variation in estimation outcomes on the migration elasticity. In the present sub-section we follow a descriptive approach to this variation, while in the next subsection 4.3 a multivariate analysis will be carried out. Special attention is given to the role of education levels and the skill of migrants.

Table 2: Descriptive statistics by country

\begin{tabular}{|l|c|c|c|c|c|c|c|c|}
\hline & \multicolumn{4}{|c}{ Outward FDI } & \multicolumn{3}{c|}{ Inward FDI } \\
\hline Country & Nr obs & Mean & Minimum & Maximum & Nr obs & Mean & Minimum & Maximum \\
\hline China & NA & NA & NA & NA & 2 & 0.274 & 0.252 & 0.295 \\
\hline EU15 & NA & NA & NA & NA & 7 & 0.836 & 0.106 & 2.956 \\
\hline France & 14 & 0.398 & -0.054 & 1.014 & 14 & 0.456 & -0.615 & 1.754 \\
\hline Germany & 12 & 0.278 & -0.048 & 0.609 & 14 & 0.256 & -0.637 & 1.243 \\
\hline Italy & 37 & 0.187 & -0.620 & 1.063 & 37 & 0.116 & -0.810 & 0.0821 \\
\hline OECD & 9 & 0.617 & 0.029 & 1.467 & 13 & 0.418 & -0.154 & 1.835 \\
\hline Spain & 18 & 0.418 & -0.690 & 1.282 & 18 & 0.407 & -1.398 & 1.628 \\
\hline UK & 20 & 0.466 & -0.779 & 1.703 & 20 & 0.351 & -1.596 & 3.004 \\
\hline US & 30 & 0.407 & 0.084 & 0.667 & NA & NA & NA & NA \\
\hline Total & $\mathbf{1 4 0}$ & $\mathbf{0 . 3 6 0}$ & $\mathbf{- 0 . 7 7 9}$ & $\mathbf{1 . 7 0 3}$ & $\mathbf{1 2 5}$ & $\mathbf{0 . 3 2 4}$ & $\mathbf{- 1 . 5 9 6}$ & $\mathbf{3 . 0 0 4}$ \\
\hline
\end{tabular}

Table 2 shows that the mean elasticity of outward and inward FDI is positive, and the elasticity of outward FDI is slightly higher (0.360) than for inward FDI (0.324). Furthermore, we have studies where various levels of migrants' education and skills are distinguished, and our data suggests that there is a difference in impacts with respect to the education levels and skills of immigrants. Table 3 below shows the education and skill impact of migrants on the outward and the inward FDI. For example, for outward FDI we find a mean elasticity of 0.532 for higher-educated migrants and -0.478 for poorlyeducated migrants, and for inward FDI the gaps are even bigger. If we look at the skill level of immigrants in outward FDI, we can see that skilled migrants have a positive mean elasticity of 0.657 , while low-skilled migrants have a negative mean elasticity of -0.203 . The impacts of skilled and low- 
skilled migrants are even bigger in inward FDI. Furthermore, we also have some estimates for the effect of diasporas. Table 4 shows the impact of diasporas on outward and inward FDI investment in the studies. The mean values for diasporas are remarkably close to each other for the various categories in the table (about 0.45)

Table 3: Descriptive statistics by immigrant's education and skill level

\begin{tabular}{|l|c|c|c|c|c|c|c|c|}
\hline & \multicolumn{4}{|c|}{ Outward FDI } & \multicolumn{4}{c|}{ Inward FDI } \\
\hline Education level & nr obs & mean & min & max & nr obs & mean & min & max \\
\hline Higher-educated migrants & 12 & 0.532 & 0.134 & 1.260 & 2 & 2.243 & 1.481 & 3.004 \\
\hline Poorly-educated migrants & 2 & -0.478 & -0.497 & -0.458 & 2 & -1.125 & -1.596 & -0.708 \\
\hline Skilled-migrants & 37 & 0.657 & -0.365 & 1.703 & 37 & 0.992 & -0.098 & 2.603 \\
\hline Low-skilled migrants & 29 & -0.203 & -0.779 & 0.36 & 31 & -0.575 & -1.398 & 0.008 \\
\hline
\end{tabular}

Table 4: Descriptive statistics by emigrant category

\begin{tabular}{|l|c|c|c|c|c|c|c|c|}
\hline & \multicolumn{4}{|c|}{ Outward FDI } & \multicolumn{4}{c|}{ Inward FDI } \\
\hline Emigrant & nr obs & mean & min & max & nr obs & mean & min & max \\
\hline Diaspora & 4 & 0.482 & 0.293 & 0.749 & 9 & 0.419 & 0.250 & 0.805 \\
\hline diaspora in OECD & 4 & 0.319 & -0.007 & 0.602 & 4 & 0.434 & 0.048 & 0.803 \\
\hline diaspora in non-OECD & 4 & 0.474 & 0.055 & 0.823 & 4 & 0.458 & 0.043 & 0.809 \\
\hline
\end{tabular}

Note that the mean values reported in Tables 2, 3 and 4 do not represent the statistical significance of the estimated elasticities. Therefore, we calculated the weighted average, which includes the statistical significance of the effect size. This calculation can be made in two ways. First, there is the fixed effect (FE) method that takes into account a true effect size, which underlies all the estimates within a certain study, and all differences in effect sizes (elasticity estimates) within a study are due to sampling errors. In the fixed-effect approach the weight assigned to each effect size is then the inverse of its variance (Genc et al. 2010). Secondly, there is the random effect (RE) method that assumes that the true effect size varies from study to study in a stochastic way.

Table 5 presents the FE and RE weighted means effects of immigration on outward and inward FDI. As we can see, the FE model shows that migration has a positive impact on outward FDI. The same holds true for inward FDI, although in some cases slightly positive values are found. In total, the FE weighted-mean effect of immigration is slightly bigger for outward FDI (0.196) than for inward FDI (0.176). 
Table 5: Weighted mean effect sizes by country

\begin{tabular}{|l|c|c|c|c|c|c|}
\hline & \multicolumn{3}{|c|}{ Outward FDI } & \multicolumn{3}{c|}{ Inward FDI } \\
\hline Country & Nr obs & FE & RE & Nr obs & FE & RE \\
\hline China & NA & NA & NA & 2 & 0.281 & 0.281 \\
\hline EU15 & NA & NA & NA & 7 & 0.209 & 0.287 \\
\hline France & 14 & 0.337 & 0.333 & 14 & 0.181 & 0.330 \\
\hline Germany & 12 & 0.064 & 0.231 & 14 & -0.019 & 0.182 \\
\hline Italy & 37 & 0.213 & 0.226 & 37 & 0.207 & 0.177 \\
\hline OECD & 9 & 0.249 & 0.336 & 13 & 0.208 & 0.204 \\
\hline Spain & 18 & 0.512 & 0.421 & 18 & 0.444 & 0.338 \\
\hline UK & 20 & 0.181 & 0.384 & 20 & -0.068 & 0.115 \\
\hline US & 30 & 0.302 & 0.343 & NA & NA & NA \\
\hline Total & $\mathbf{1 4 0}$ & $\mathbf{0 . 1 9 6}$ & $\mathbf{0 . 3 0 5}$ & $\mathbf{1 2 5}$ & $\mathbf{0 . 1 7 6}$ & $\mathbf{0 . 1 8 7}$ \\
\hline
\end{tabular}

The scatter plot between the migration elasticity of outward FDI and the migration elasticity of inward FDI for the studies, where both are available, shows a positive relationship (Figure 1). The correlation coefficient is 0.79 .

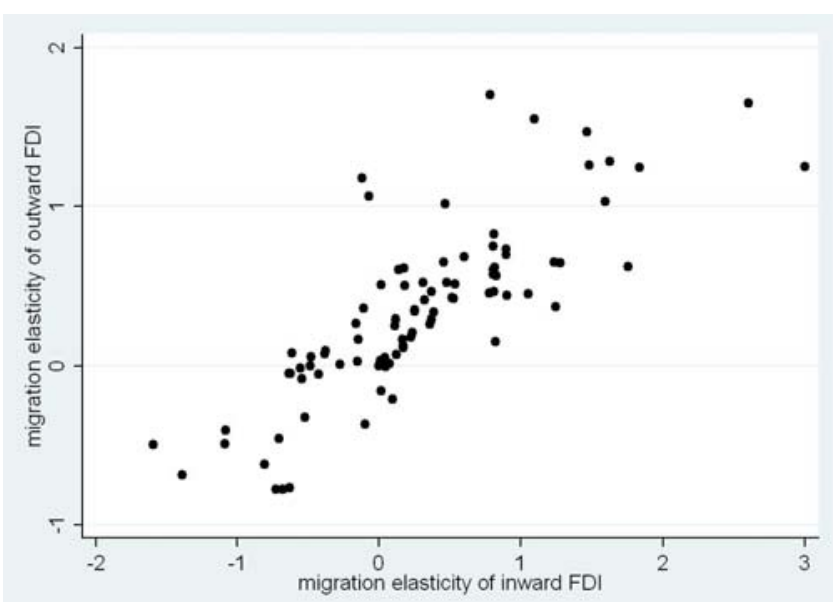

Figure 1: Scatter plot of the migration elasticity of outward and inward FDI when estimated jointly

In addition, the weighted and unweighted means of migration on outward and inward FDI by articles published in journals or unpublished are given in Table 6 below. The differences between the various means for the published and unpublished estimates are modest.Of the 140 effect sizes for outward FDI, 38 (27 per cent) come from journal articles. For inward FDI, from 125 effect sizes, 10 (8 per cent) come from journal articles. 
Table 6: Unweighted and weighted mean elasticities by publication type

\begin{tabular}{|l|c|c|c|c|c|c|c|c|}
\hline & \multicolumn{4}{|c|}{ Outward FDI } & \multicolumn{4}{c|}{ Inward FDI } \\
\hline Outlet & Freq. & Mean & FE & RE & Freq. & Mean & FE & RE \\
\hline Journal & 38 & 0.366 & 0.375 & 0.344 & 10 & 0.134 & 0.252 & 0.248 \\
\hline Unpublished & 102 & 0.358 & 0.382 & 0.277 & 115 & 0.340 & 0.163 & 0.185 \\
\hline Total & $\mathbf{1 4 0}$ & $\mathbf{0 . 3 6 0}$ & $\mathbf{0 . 1 9 6}$ & $\mathbf{0 . 3 0 5}$ & $\mathbf{1 2 5}$ & $\mathbf{0 . 3 2 4}$ & $\mathbf{0 . 1 7 6}$ & $\mathbf{0 . 1 8 7}$ \\
\hline
\end{tabular}

In Figures 2 and 3 the effect sizes are plotted against their standard error for a measure precision. The vertical axis presents the standard errors of the effect sizes, and the elasticities are measured along the horizontal axis. The broken line indicates the expected 95 per cent confidence intervals for a given standard error, assuming no heterogeneity between studies. In general, a large set of observations outside the 95 per cent confidence intervals indicates a wide range of estimates, and provide the evidence of publication bias. In our funnel plot (Figures 2 and 3 ) the outliers are mostly from unpublished articles. Furthermore, the meta-regression model is demonstrated to be better at removing the heterogeneity in the both directions of FDI (outward and inward).
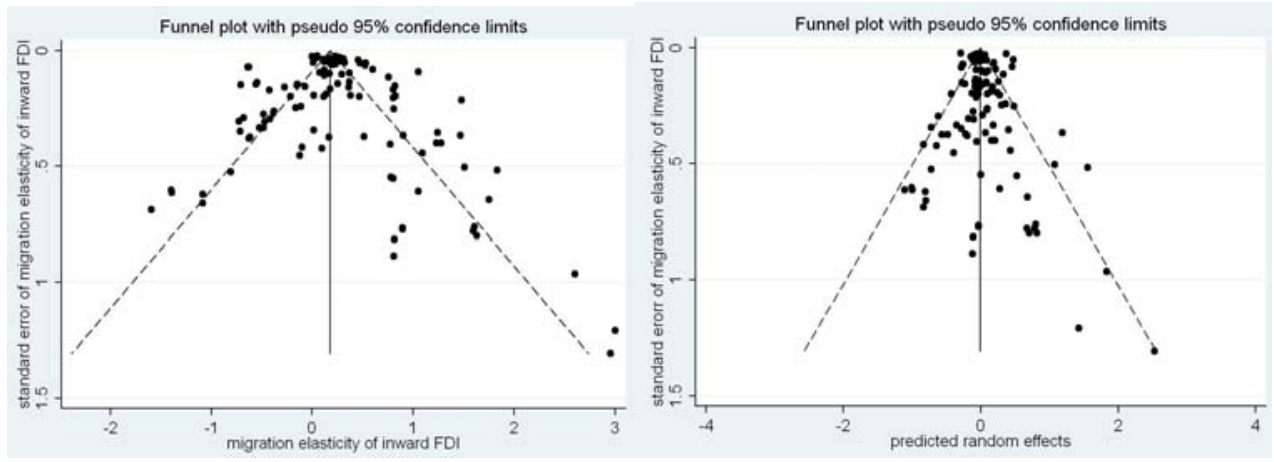

Figure 2: The impact on publication bias of controlling for heterogeneity in the random effects metaregression model - inward FDI
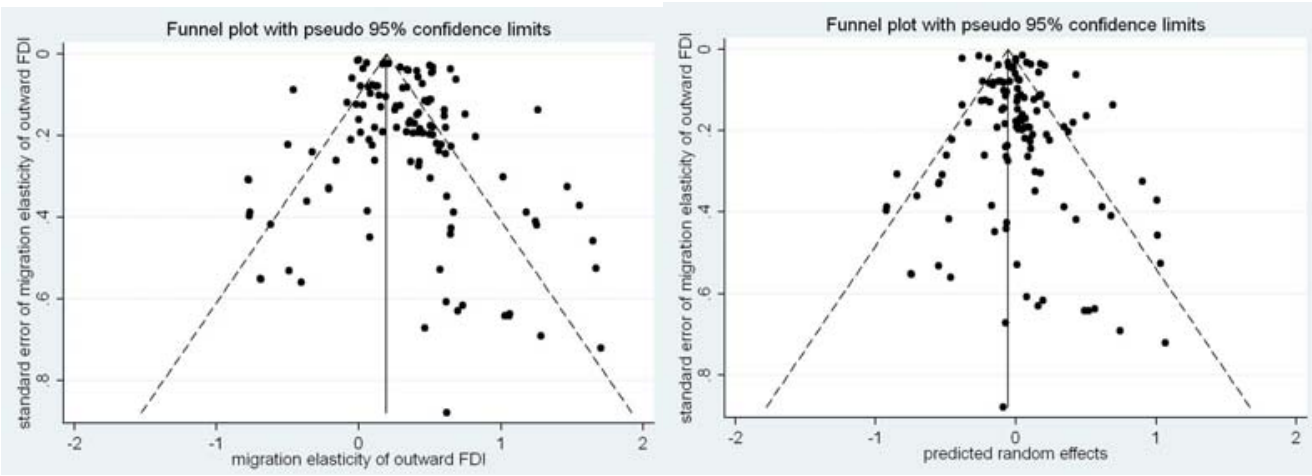

Figure 3: The impact on publication bias of controlling for heterogeneity in the random effects metaregression model - outward FDI 
Our studies also differ by the estimation method used. Table 7 summarizes the mean elasticity estimates obtained by different estimation methods. For outward FDI, a large number of estimates are obtained by OLS, that is, 107 out of 140 estimates (76.4 per cent), and 25 out of 140 (17.9 per cent) are obtained by IV/3SLS/GMM by model estimation. For inward FDI, the share of estimates by OLS is even higher, with 102 out of 125 (81.6 per cent), and 12 out of 125 (9.6 per cent) are obtained by a Tobit model. Furthermore, if we look at the FE and RE results in outward FDI, we can see that IV/3SLS/GMM has bigger estimates than those obtained for OLS and Tobit. For inward FDI, the ordinary and weighted (FE, RE) estimates obtained by IV/3SLS/GMM are again larger than the others.

Table 7 : Unweighted and weighted mean elasticities by estimation method

\begin{tabular}{|l|c|c|c|c|c|c|c|c|}
\hline & \multicolumn{4}{|c|}{ Outward FDI } & \multicolumn{4}{c|}{ Inward FDI } \\
\hline Method & Freq. & Mean & FE & RE & Freq. & Mean & FE & RE \\
\hline OLS & 107 & 0.302 & 0.172 & 0.263 & 102 & 0.276 & 0.160 & 0.170 \\
\hline IV/3SLS/GMM & 25 & 0.520 & 0.480 & 0.455 & 11 & 0.643 & 0.221 & 0.274 \\
\hline Tobit & 8 & 0.632 & 0.191 & 0.227 & 12 & 0.438 & 0.211 & 0.207 \\
\hline Total & $\mathbf{1 4 0}$ & $\mathbf{0 . 3 6 0}$ & $\mathbf{0 . 1 9 6}$ & $\mathbf{0 . 3 0 5}$ & $\mathbf{1 2 5}$ & $\mathbf{0 . 3 2 4}$ & $\mathbf{0 . 1 7 6}$ & $\mathbf{0 . 1 8 7}$ \\
\hline
\end{tabular}

\subsection{Regression results}

After the descriptive analysis of Section 4.2, we will now run a meta-analysis regression on our database to find out whether the differences in the results between studies can be related to the characteristics of these studies in a multivariate setting. The basic equation is as follows:

$$
y_{i}=\mathbf{x}_{i} \boldsymbol{\beta}+u_{i}+\varepsilon_{i},
$$

where $y_{i}$ represents the effect size from study $i$, and $x_{i}$ is the set of study characteristics that are considered to have an impact on the effect sizes of the reported standard error. The algorithm we use in this study is based on the Restricted Maximum Likelihood (REML) method, which maximizes the residual log-likelihood function (see Harbord and Higgings 2000 for details). The estimation of equation (1) is done separately for the effect sizes for outward and inward FDI.

The OLS method is the reference method in our regression. We can see that elasticities for outward FDI based on estimates by means of IV are significantly larger than the OLS-based elasticities. The estimates by means of Tobit appear to be smaller than the OLS results; however, the difference is not statistically significant. For inward FDI we do not find a significant difference between the elasticities based on the various estimation methods. Table 8 gives the description of our variables, while Table 9 shows the estimate results. 
Table 8: Study characteristics included in meta-regression

\begin{tabular}{|c|c|c|}
\hline Variable & Description & Mean value \\
\hline iv & Equals 1 if the estimation method is IV/3SLS/GMM/FGLS, 0 if it is OLS & 0.174 \\
\hline Tobit & Equals 1 if the estimation method is Tobit, 0 if it is OLS & 0.072 \\
\hline mighigher & $\begin{array}{l}\text { Equals } 1 \text { if the elasticity is estimated for immigration with higher educated, } \\
0 \text { if no distinction is made between education levels }\end{array}$ & 0.072 \\
\hline migpoorly & $\begin{array}{l}\text { Equals } 1 \text { if the elasticity is estimated for immigration with poorly educated, } \\
0 \text { if no distinction is made between education levels }\end{array}$ & 0.012 \\
\hline migskilled & $\begin{array}{l}\text { Equals } 1 \text { if the elasticity is estimated for skilled immigration, } 0 \text { if no } \\
\text { distinction is made }\end{array}$ & 0.258 \\
\hline miglowskiled & $\begin{array}{l}\text { Equals } 1 \text { if the elasticity is estimated for low-skilled immigration, } 0 \text { if no } \\
\text { distinction is made }\end{array}$ & 0.210 \\
\hline diasporas & Equals 1 if the elasticity is estimated for emigrants, 0 otherwise & 0.054 \\
\hline oecd-diasporas & $\begin{array}{l}\text { Equals } 1 \text { if the elasticity is estimated for emigrants to OECD countries, } 0 \\
\text { otherwise }\end{array}$ & 0.024 \\
\hline non-oecd-diasporas & $\begin{array}{l}\text { Equals } 1 \text { if the elasticity is estimated for emigrants to non-OECD countries, } \\
0 \text { otherwise }\end{array}$ & 0.024 \\
\hline population & Equals 1 if population is included in the specification, 0 otherwise & 0.216 \\
\hline institq & Equals 1 if institutional quality is included in the specification, 0 otherwise & 0.862 \\
\hline distance & Equals 1 if distance is included in the specification, 0 otherwise & 0.934 \\
\hline colonial tie & Equals 1 if colonial tie is included in the specification, 0 otherwise & 0.311 \\
\hline conflict & Equals 1 if conflict is included in the specification, 0 otherwise & 0.180 \\
\hline journal & $\begin{array}{l}\text { Equals } 1 \text { if elasticity is estimated in articles published in journals, } 0 \\
\text { otherwise }\end{array}$ & 0.240 \\
\hline
\end{tabular}

The results on the education of migrants show that education matters. For example, the result of 1.467 for higher-educated migrants in inward FDI means that, compared with the reference case where the total stock of migrants is considered (not distinguished according to education level), the migration elasticity is 1.467 higher when highly-educated migrants are considered. For outward FDI we did not find such a significant result. However, the elasticity is larger than in the reference case. Along similar lines, for both inward and outward FDI we find that for poorly educated migrants the elasticity of FDI is significantly lower compared with the reference case where the education level is not considered. Similar results as to those for educated migrants are found for skilled and low-skilled migrants. The skilled migrants elasticity is 0.717 higher in inward FDI compared with the reference case (total stock of migrants). However, the elasticity of skilled migrants is larger than the reference case, but it is statistically insignificant for the outward FDI. For low-skilled migrants the elasticity of FDI is significantly lower than that for the total stock of migrants in both inward and outward FDI, respectively. The 
elasticity for the 'diasporas' which is estimated in Murat and Pistoresi (2009) and Murat and Flisi (2007, 2009) is significantly larger for both outward (0.287) and inward (0.352) FDI compared with the reference case where the elasticity pertains to immigration. Similar results are also found for the diasporas living in OECD (0.277) and non-OECD (0.289) countries in inward FDI. Thus, we observe a tendency that, for the countries (Italy and Spain) considered here, emigration has a stronger effect on FDI than immigration.

The inclusion of population as a proxy for the size of the market in the gravity model has a positive statistically significant effect on outward FDI. The inclusion of the geographical distance in the gravity model has a negative effect on the estimated elasticities, and it is statistically significant for outward FDI. A negative coefficient is found for the inclusion of a conflict variable in the gravity model. In general one would expect that conflicts between countries ${ }^{1}$ have a dampening effect on both migration and on FDI. Hence, when one ignores the effect of conflict on FDI, part of the impact of conflict is picked up by the migration variable.

A related result is found for the colonial tie variable. Colonial ties are expected to stimulate both migration and FDI. When colonial ties are not included in the gravity model for FDI, the colonial ties effect would be partly represented by the migration variable. Interestingly enough, explicitly including colonial ties in the gravity model leads to a higher elasticity of FDI with respect to migration. This suggests that colonial ties reinforce the FDI-stimulating effect of migration. The elasticities estimated in articles published in international journals for outward FDI are significantly lower than those the unpublished articles. For inward FDI, however, the elasticity is lower than the reference case (unpublished article), but it is statistically insignificant.

\section{Conclusion}

In this paper we have analysed the distribution of immigration elasticities of inward and outward across nine studies that yielded 167 estimates. The results confirm that immigration boosts FDI investment, and that by taking into account the education level of migrants, higher-educated migrants have a larger effect on inward FDI. The average elasticities found are moderate: in the range from 0.196 to 0.305 for outward FDI, and 0.176 to 0.187 for inward FDI.

\footnotetext{
${ }^{1}$ This variable is dropped from inward FDI, because the studies for inward or combined estimation of inward and outward FDI did not include conflict as an explanatory variable in their estimations.
} 
Table 9: Meta-regression results of migrant stock elasticity of FDI

\begin{tabular}{|c|c|c|}
\hline VARIABLES & Outward FDI & Inward FDI \\
\hline \multirow[t]{2}{*}{ iv } & $0.241 * * *$ & 0.062 \\
\hline & $(0.080)$ & $(0.144)$ \\
\hline \multirow[t]{2}{*}{ tobit } & -0.213 & -0.103 \\
\hline & $(0.210)$ & $(0.136)$ \\
\hline \multirow{2}{*}{ mighigher } & 0.076 & $1.467^{* * *}$ \\
\hline & $(0.092)$ & $(0.389)$ \\
\hline \multirow[t]{2}{*}{ migpoorly } & $-1.172^{* * *}$ & $-0.901 * * *$ \\
\hline & $(0.224)$ & $(0.334)$ \\
\hline \multirow[t]{2}{*}{ migskilled } & 0.136 & $0.717^{* * *}$ \\
\hline & $(0.106)$ & $(0.123)$ \\
\hline \multirow[t]{2}{*}{ miglowskiled } & $-0.342 * * *$ & $-0.520 * * *$ \\
\hline & $(0.0996)$ & $(0.109)$ \\
\hline \multirow[t]{2}{*}{ diasporas } & $0.287^{* * *}$ & $0.352 * * *$ \\
\hline & $(0.102)$ & $(0.113)$ \\
\hline \multirow{2}{*}{ Diasporas in OECD } & -0.016 & $0.277^{*}$ \\
\hline & $(0.102)$ & $(0.154)$ \\
\hline \multirow[t]{2}{*}{ Diasporas in non-OECD } & 0.127 & $0.289^{*}$ \\
\hline & $(0.141)$ & $(0.158)$ \\
\hline \multirow[t]{2}{*}{ Population } & $0.364^{* *}$ & 0.015 \\
\hline & $(0.162)$ & $(0.229)$ \\
\hline \multirow[t]{2}{*}{ Institq } & -0.102 & -0.152 \\
\hline & $(0.169)$ & $(0.111)$ \\
\hline \multirow[t]{2}{*}{ Conflict } & -0.256 & \\
\hline & $(0.180)$ & \\
\hline \multirow[t]{2}{*}{ colonial tie } & $0.213^{* * *}$ & $0.148^{*}$ \\
\hline & $(0.083)$ & $(0.089)$ \\
\hline \multirow[t]{2}{*}{ Distance } & $-0.232^{*}$ & -0.231 \\
\hline & $(0.0997)$ & $(0.168)$ \\
\hline \multirow[t]{2}{*}{ Journal } & $-0.204 * * *$ & -0.120 \\
\hline & $(0.113)$ & $(0.098)$ \\
\hline \multirow[t]{2}{*}{ Constant } & $0.395 * * *$ & $0.461^{* * *}$ \\
\hline & $(0.216)$ & $(0.15)$ \\
\hline Observations & 140 & 125 \\
\hline Adj R-squared & 0.65 & 0.85 \\
\hline
\end{tabular}

Our meta-analysis shows that the strongest factor explaining variations in study results is the education level and level of skill of migrants. Highly-educated and skilled migrants lead to considerably higher FDI levels (in particular for inward FDI), whereas poorly-educated and low-skilled migrants have a large and negative effect on both inward and outward FDI. The estimated migration elasticities show that international networks in the sphere of human capital have reinforcing impacts on networks in terms of capital flows. This holds particularly for highly educated people. For poorly educated people a 
different mechanism seems to dominate. The negative impact of education level and skill level on FDI indicates that large numbers of poorly educated and low-skilled migrants flowing into a country suggest that the sending country is not an attractive place for FDI investments. Apparently, it is not the network effect that dominates but the fact that large migration flows of low-educated people appear to be a negative signal for investment opportunities abroad.

\section{References}

Bakens, J., and P. Nijkamp(2010) Lessons from migration impact analysis. Revista Portuguesa de Estudos Regionais. 24: 5-16.

Baltagi, H. B., P. Egger., and M. Pfaffermayr (2007) Estimating models of complex FDI: are there third -country effects?. Journal of Econometrics. 140: 260-281.

Baycan-Levent, T (2010) Diversity and creativity as seedbeds for urban and regional dynamics. European Planning Studies. 18: 565-594.

Baycan-Levent, T., and P. Nijkamp (2009) Characteristics of migrant entrepreneurship in Europe. Entrepreneurship and Regional Development. 21: 375-398.

Baycan-Levent, T., P. Nijkamp., and M. Sahin (2009) New orientations in ethnic entrepreneurship: motivation, goals and strategies of new generation ethnic entrepreneurs. International Journal of Foresight and Innovation Policy. 5: 83-112.

Berkhout, E.E., C. Dustmann and P. Emmer (2007) Mind the gap: international database on employment and adaptable labour (IDEAL). SEO Report no. 968. SEO Economic Research, Amsterdam.

Blanes-Cristóbal, J.V (2003) The link between immigration and trade in Spain. Universidad Pablo de Olavide, Sevilla. Boeri, T. and H. Brücker(2005) Why are Europeans so tough on migrants?. Economic Policy. 20: 629-703.

Borjas, G.J (2005) Foreign-born domestic supply of science and engineering workforce. American Economic Review. 95: 56-60.

Brander, L.M., van Beukering, and H.S.J. Cesar (2007) The recreational value of coral reefs: a meta-analysis. Ecological Economics. 63: 209-218.

Bryant, J., M. Genç and D. Law (2004) Trade and migration to New Zealand, Working Paper No. 2004/18. New Zealand Treasury, Wellington NZ.

CAA (Civil Aviation Authority) (2009) International relations: the growth in air travel to visit friends or relatives. The United Kingdom Government.

Caldwell, C. (2009) Reflections on The Revolution in Europe: Immigration, Islam and the West. Doubleday, New York.

Card, D., J. Kluve., and A. Weber (2010) Active labour market policy evaluations: A meta-analysis. The Economic Journal. 120: 452-477.

Chatwin, B (1988) What Am I Doing Here?. Penguin, London.

Chia, S.Y (2006) Labor mobility and East Asian integration. Asian Economic Policy Review. 1: 349-367.

Ching, H.S. and L.L. Chen (2000) Links between emigrants and the home country: the case of trade between Taiwan and Canada. Regional Cohesion and Competition in the Age of Globalization (H. Kohno, P. Nijkamp and J. Poot, eds). Edward Elgar, Cheltenham.

Cipollina, M., and L. Salvatici (2010) Reciprocal trade agreements in gravity models: a meta-analysis. Review of International Economics. 18: 63-80.

Cohen, A.J., and N.G. Harris (1998) Mode choice for VFR journeys. Journal of Transport Geography. 6: 43-51.

Combes, P., M. Lafourcade and T. Mayer (2003) Can business and social networks explain the border effect puzzle?. Working Paper No. 2003-02, Ventre d'Etudes Prospectives et d'Informations Internationals (CEPII). Paris. 
Dagevos, J., Hoge (Jeugd) werkloosheid onder Etnische Minderheden, SCP, Den Haag, 2006, http://www.integratie.net/binaries/kiem/bulk/onderzoek/2006/1/hoge-werkloosheid-onder-etnischeminderheden-scp.pdf

Dolman, B (2007) Patterns of migration, trade and foreign direct investment across OECD countries. Paper presented at the $12^{\text {th }}$ Dynamics, Economic Growth and International Trade Conference. Australia. 29-30 June.

Dunlevy, J. A. and W.K. Hutchinson (1999) The impact of immigration on American import trade in the late nineteenth and early twentieth centuries. Journal of Economic History. 59: 1043-1062.

Dwyer, L., I. Burnley, P. Forsyth, and P. Murphy (1993) Tourism - immigration interrelationships, Report Paper. Bureau of Immigration and Population Research, Canberra, Australia.

Gao, T (2003) Ethnic Chinese networks and international investment: evidence from inward FDI in China. Journal of Asian Economics. 14: 611-629.

GCIM (2005) Migration in an International World, Global Commission on International Migration, Geneva.

Genc, M., M. Gheasi, P. Nijkamp and J. Poot (2010) The impact of immigration on international trade: A metaanalysis. Paper presented at the Migrant Diversity and Regional Disparity in Europe (MID-REDIE) workshop, Helsinki, 18-19 November.

Gera, S., S.A. Laryea and T. Songsakul (2004) International mobility of skilled labour: analytical and empirical issues and research priorities. Econ WPA 2004 D-01 (online).

Gheasi , M., P. Nijkamp., and P. Rietveld (2011) Migration and foreign direct investment: education matters. Tinbergen Institute Discussion Paper, No 136/3.

Gheasi, M., P. Nijkamp and P. Rietveld (2011) Migration and tourist flows. Advances in Tourism Economics (A. Matias and P. Nijkamp, eds.), Physika-Verlag, Heidelberg.

Girma, S. and Z. Yu (2002) The link between immigration and trade: evidence from the United Kingdom, Weltwirtschaftliches Archiv. 138: 115-130.

Glass, G.V., and M.L. Smith (1979) Meta-analysis of research in class size and achievement. Educational Evaluation and Policy Analysis. 1:2-16.

Goldin, I., G. Cameron., and M. Balarajan (2011) Exceptional people. Princeton University Press, Princeton.

Gould, D (1994) Immigration links to the home country: empirical implications for US bilateral trade flows. Review of Economics and Statistics. 76: 302-316.

Harbord, R.M. and., J.P.T Higgins (2000) Meta-regression in Stata. Stata Journal. 8: 493-519.

Hatton, T.J (2007) Should we have a WTO for international migration? Economic Policy. 22: 339-383.

Hatton, T. and J. Williamson (2006) Migration and the world economy, MIT Press, Cambridge (MA).

Holmgren, J (2007) Meta-analysis of public transport demand. Transportation Research Part A: Policy and Practice.

41: 1021-1035.

IOM (2010) Word Migration Report. The Future of Migration: Building Capacities for Change, http://publications.iom.int/bookstore/free/WMR_2010_ENGLISH.pdf, Access 3/6/2011

Jacobs, J (1961) The death and life of great American cities. Vintage Books, New York.

Javorcik, B., C. Ozden., M. Spatareanu., and C. Neagu (2010) Migrant networks and foreign direct investment. Journal of Development Economics. 94: 231-241.

Kaufmaan, D., Kraay, A. \& Mastruzzi, M. (2009) Governance Matters VIII: Aggregate and Individual Governance Indicators, 1996-2008. World Bank Policy Research Working Paper, No. 4978.

Kourtit, K., and P. Nijkamp (2011) Strangers on the move: ethnic entrepreneurs as urban change actors. Journal of Entrepreneurship \& Regional Development (forthcoming).

Kugler, M. and H. Rapoport (2007) International labor and capital flows: complements or substitutes?. Economics Letters. 94:155-162.

Law, D., M. Gonc and J. Bryant (2009) Trade, diaspora and migration to New Zealand. NZ Institute for Economic Research, Wellington, NZ.

Leeuwen, E. van, P. Nijkamp and P. Rietveld (2009) A meta-analytic comparison of regional output multipliers at different spatial levels: economic impacts of tourism. In: Advances in Tourism Economics: New Developments (A. Matias, P. Nijkamp and M. Sarmento, eds.), Physika-Verlag, Heidelberg: 13-33. 
Lewer, J.J., and H. van den Berg (2009) Does immigration stimulate international trade? measuring the channels of influence. The International Trade Journal. 23: 187-230.

Longhi S., P. Nijkamp and J. Poot (2005a) A meta-analytic assessment of the effect of immigration on wages. Journal of Economic Surveys. 19: 451-477.

Longhi, S., P. Nijkamp and J. Poot (2005b) The fallacy of "Job Robbing": A meta-analysis of estimates of the effect of immigration on employment. Journal of Migration and Refugee Issues. 1: 131-152.

Longhi, S., P. Nijkamp and J. Poot (2008a) Meta-analysis of empirical evidence on the labour market impact of immigration. Région et Développement. 27: 161-191.

Longhi, S., P. Nijkamp and J. Poot (2008b) The impact of immigration on the employment of natives in regional labour markets: A meta-analysis. Migration and Human Capital (J. Poot, B. Waldorf and L. van Wissen, eds.). Edward Elgar, Cheltenham:173-193.

Longhi, S., P. Nijkamp and J. Poot (2009) Joint impacts of immigration on wages and employment: review and meta-analysis. Journal of Geographical Systems. 12: 355-387.

Matias, A., P. Nijkamp, and P. Neto (eds.) (2007) Advances in modern tourism research: Economic perspectives. Physika-Verlag, Heidelberg.

Matias, A., P. Nijkamp and M. Sarmento (eds) (2009) Advances in tourism economics: New developments. PhysikaVerlag, Heidelberg.

Mattoo, A. and A. Carzaniga (2003) Moving people to deliver services. World Bank, Washington DC.

Mundra, K (2005) Immigration and international trade: a Semiparametric empirical investigation. The Journal of International Trade and Economic Development. 14: 65-91.

Münz, R., Th. Straubhaar, F. Vadean and N. Vadean (2006) Costs and benefits of European immigration. OECD, Paris.

Murat, M., and Pistoresi, B (2009) Emigrants and immigrants networks in FDI. Journal of Applied Economic Letters. 16: $1261-1264$

Murat, M., and Flisi, S (2007) Migrants business networks and FDI. Center for Economic Research working papers 2.

Murat, M., and Flisi, S (2009) Immigrant links, diasporas and FDI: an empirical investigation on five European countries. Center for Economic Research working papers 32. Modena.

Nijkamp, P (2010) The age of migration. Dept. of Spatial Economics. VU University, Amsterdam.

Nijkamp, P., M. Sahin and T. Baycan-Levent (2010) Migrant entrepreneurship and new urban economic opportunities: identification of critical success factors by means of qualitative pattern recognition analysis. Journal of Economic and Social Geography. 101: 371-391.

Nijkamp, P., and J. Poot (2011) Regional economic impact of migration. Migration Impact Assessment ( P. Nijkamp., J. Poot., and M. Sahin eds.), Edward Elgar, Cheltenham (forthcoming).

ODI (Overseas Development Institute), Mapping the global partnership for development, London, 2008, http://www.odi.org.uk/projects/documents/530-data-collecton-template-migration.pdf.

OECD (2003) OECD Economic Surveys: Spain, OECD Economic Surveys 2003/7. Organisation for Economic Cooperation and Development, Paris.

OECD (2009) The future of international migration to OECD countries. OECD, Paris.

Ozgen, C., P. Nijkamp and J. Poot (2010a) The effect of migration on income convergence: Meta-analytic evidence, Papers in Regional Science. 89: 537-561.

Ozgen, D., P. Nijkamp and J. Poot (2010b) Migrant diversity and spatial innovation patterns in Europe. paper presented at the ERSA conference, Lodz.

Pekkala, S (2005) Economic impacts of immigration; a survey. Government Institute for Economic Research (VATT). Discussion paper no. 362, Helsinki.

Plane, D.A., and L. Hoffman (2009) Immigration in the USA. International Handbook of Urban Policy (H.S. Geyer, ed.), Edward Elgar, Cheltenham: 259-275.

Poot, J (2008) Demographic change and regional competitiveness: the effects of immigration and ageing. International Journal of Foresight and Innovation Policy. 4: 129-145.

Poot, J. and A. Strutt (2009) International trade agreements and international migration. The World Economy. 33: 1923-1954.

Poot, J., B. Waldorf and L. van Wissen (eds.) (2008) Migration and human capital. Edward Elgar, Cheltenham, UK. 
Rauch, J. E., and V. Trindade. (2002) Ethnic Chinese networks in international trade. Review of Economics and Statistics. 84: 116-130.

Sahin, M., P. Nijkamp and T. Baycan Levent (2007) Multicultural diversity and migrant entrepreneurship: The case of the Netherlands. ITU A/Z. 4: 22-46.

Sahin, M., P. Nijkamp and R. Stough (2010) Impact of urban conditions on firm performance of migrant entrepreneurs: a comparative Dutch-US study. The Annals of Regional Science. 46: 661-689.

Samuel, J. and S. George (2002) Globalization, migration and development. Canadian Studies in Population. 29: 3152.

Sarvimäki, M (2009) Essays on migration. Government Institute for Economic Research (VATT), Helsinki.

Saxenian, A (2007) Brain circulation and regional innovation: the Silicon Valley-Hsinchu-Shanghai triangle. The Economic Geography of Innovation (K. Polenske, ed.), Cambridge University Press, Cambridge: 190-211.

Seaton, A.V., and C. Palmer (1997) Understanding VFR tourism behaviour: the first five years of the United Kingdom tourism survey. Tourism Management. 18: 345-355.

Seetaram, N (2008) Immigration and tourism demand: evidence from Australia, paper presented at the CAUTHE 2008 Conference, Australia.

Simone, G.de, M. Machin (2010) Outward migration and inward FDI: factor mobility between eastern and western Europe. Paper presented at the $10^{\text {th }}$ ETSG annual conference. Warsaw.

Snel, E. and J. Burgers (2000) The comfort of strangers - etnische enclaves in de grote steden. Amsterdams Sociologisch Tijdschrift. 27: 292-313.

UNDP (2009) Overcoming barriers: human barriers and development. Human Development Report. United National Development Programme, New York.

United Nations (2004) World economic and social survey 2004; international migration. UN Department of Economic and Social Affairs, New York.

Waldinger, R., H. Aldrich and R. Ward (eds)(1990) Ethnic entrepreneurs: immigrant business in industrial societies. Sage, Newbury Park, CA.

White, R (2007) Immigrant-trade links, transplanted home bias and network effects. Applied Economics. 39: 839852.

Williams, A. M. and C.M. Hall (2000) Tourism and migration: new relationships between production and consumption. Tourism Geographies. 2: 5-27.

Wolf, H.C (2000) International home bias in trade. Review of Economics and Statistics. 82: 555-563.

World Bank (2006) Global Economic Prospects. Economic Implications of Remittances and Migration, Washington DC.

WTTC (World Travel and Tourism Council), Blueprint for New Tourism, WTTC, London, 2006, www.sttc.com 